\title{
SPEED OF ADJUSTMENT TOWARD CAPITAL STRUCTURE IN CROSS BORDER AND CROSS INDUSTRY MERGERS AND ACQUISITIONS
}

\author{
DOI: 10.17261/Pressacademia.2019.1014 \\ JBEF- V.8-ISS.1-2018(4)-p.38-52
}

Irfan U. Shah ${ }^{1}$, M. Banu Durukan²

${ }^{1}$ Dokuz Eylul University, Izmir, Turkey.

Irfan.shah@ogr.deu.edu.tr, ORCID: 0000-0001-7064-0036

${ }^{2}$ Dokuz Eylul University, Izmir, Turkey.

banu.durukan@deu.edu.tr, ORCID: 0000-0002-3619-2732

Date Received: January 16, 2019

Date Accepted: March 10, 2019

To cite this document

Shah, I. U., Durukan, M. B. (2019). Speed of adjustment toward capital structure in cross border and cross industry mergers and acquisitions. Journal of Business, Economics and Finance (JBEF), V.8(1), p.38-52.

Permemant link to this document: http://doi.org/10.17261/Pressacademia.2019.1014

Copyright: Published by PressAcademia and limited licenced re-use rights only.

\section{ABSTRACT}

Purpose - In this study, the speed of adjustment (SOA) toward target capital structure is investigated in cross border and cross industry mergers and acquisitions (M\&A).

Methodology - As a measure of capital structure both book leverage (BLEV) and market leverage (MLEV) ratios are used in the analysis. The sample consists of 6,520 M\&A deals for the period of 2000-2016.

Findings - The findings show that for both the BLEV and MLEV, the cross border M\&A deals move faster toward the target capital structure compared to non-cross border M\&A deals. While the SOA rate for the same and cross industry M\&A cases does not show too much difference for BLEV and MLEV.

Conclusion - Overall the firms adjust to their target capital structure in maximum three years following the M\&A

Keywords: Speed of adjustment, cross border M\&A, cross industry M\&A, target capital structure, merger and acquisition. JEL Codes: G34, G30, F65, D53

\section{INTRODUCTION}

Capital structure is an important concern for corporate finance. Determining the optimal capital structure, maintaining a target capital structure and if deviated from the target leverage range, then rebalancing are major issues faced by managers (Auerbach, 1985; Flannery and Rangan, 2006; Jalilvand and Harris, 1984; Leary and Roberts, 2005; Marsh, 1982; Opler and Titman, 1994; Taggart, 1977). The focus of this study is mainly on the adjustment to target capital structure in cross border and cross industry M\&A deals, therefore the changes in capital structure surrounding the M\&A activities are investigated. In the literature, M\&A is considered as an expansion or organic growth for the firms (Moatti et al., 2015). Several advantages are achieved through M\&A such as; increase in market share, financial growth, operational synergies, economies of scale, tax benefits and elimination of compensation threats (Jarrell et al., 1988; Staikouras, 2006).

According to the related literature, two different scenarios are observed while considering the adjustment of capital structure and M\&A activities. The first is that M\&A decisions are made solely for financial motives and the intention of managers is to adjust to target capital structure (Leland 2007; Lewellen, 1971; Scott, 1977; Gugler and Konrad, 2002). While in the second scenario, nonfinancial motives such as; market share growth, operational synergies, economies of scales are the motives behind the M\&A decisions (Lintner, 1971, Markham, 1973, Mitchell \& Mulherin 1996, Weston 2001, Harford 2005). 
In the first case, where the motives are financial, a firm may undertake an M\&A activity to adjust to the target capital structure by targeting a firm and absorbing the debt and equity of the acquired firm (Gugler and Konrad, 2002). Vermaelen and Xu (2012) found that $80 \%$ of their M\&A sample firms out of 3,097, came closer to their target leverage, which was predicted by using Kayhan and Titman (2007) model, following the M\&A. Yang (2011) states that most of the M\&A decisions narrowed the gap between actual and target leverage ratios after the M\&A. Similarly, Leland (2007) observes that adjusting to target capital structure may be the primary motive underlying the M\&A decisions. At the same time distinguishing between different motives underlying M\&A decisions is very difficult. For example, Gugler and Konrad (2002) argue that in M\&A decisions, the financial motive may be difficult to separate from motives of increasing market power and operational synergy.

In the second case, when firms enter an M\&A deal, the financial structure as stated in the literature is expected to change and according to the tradeoff theory (Shyam-Sunder and Myers, 1999), these firms will start adjusting to target capital structure in post-M\&A period (Byoun, 2008). In a financial surplus or deficit, the firms will focus on adjusting their capital structures. Leary and Roberts (2005) state that a large number of firms is actively busy in rebalancing their leverages to sustain their targeted range. Graham and Harvey, (2001:211) states that most of the companies have flexible targets or target ranges rather than an exact status point of target capital structure, hence the capital structure fluctuates between the higher and lower ends of the range. The other reason why firms are not able to fix an optimal point as their target capital structure is due to the "cost of adjustment" (Fischer et al., 1989; Faulkender et al., 2010). In this regard, it could also be stated that adjustment to the target capital structure range may be dependent on the cost of adjustment.

If the cost of adjustment is kept constant, in other words in a frictionless world, every firm would be at its optimal capital structure. As stated by the tradeoff theory of capital structure, firms target to be at their optimal capital structure where the costs and benefits of debt and equity financing are balanced (Myers, 1984). In this context, the target capital structure depends on the cost of bankruptcy, the agency costs of debt and equity financing, the costs and benefits of signaling, and tax benefits of debt (Modigliani and Miller, 1963; Ross, 1977; Jensen and Meckling, 1976; Myers, 1977; Stulz, 1990).

In the capital structure literature, different studies have shown that firms consider a target debt ratio or a target range when making their debt decisions (Graham and Harvey, 2001; Vermaelen and Xu, 2012). Graham and Harvey (2001) found that 81\% of their survey sample of 392 CFO has admitted that they have a target debt-equity ratio or a target range. In which $71 \%$ of the firms have a flexible or somewhat tight target ratio or target range while the remaining $10 \%$ have a strict target debt ratio. Therefore, in the M\&A literature, it is found that firms adjust back to their target capital structures in post-M\&A period if they move away from their target capital structures during the M\&A (Varmaelen and Xu, 2012; Yang, 2011; Harford et al., 2009). According to Vermaelen and Xu (2012), 80\% of their M\&A sample firms move toward their target leverage ratio after the M\&A. Harford, Sandy and Nathan (2009) investigated the target leverage in the context of larger acquisitions. Their sample consisted of 1,188 takeovers of only those firms that the target firm is at least $20 \%$ of the bidder's size. They found that firms maintain a target capital structure and managers try not to divert too far from it. Their results indicated that within the first five postmerger years, 75\% of the financing effects is reversed (Harford, Sandy and Nathan, 2009: 11).

This study focuses on evaluating the speed of adjustment toward target capital structure in cross border and cross industry M\&A. The companies engaged in cross border and cross industry M\&A deals may adjust faster toward their target capital structure compared to the ones engaged in non-cross border or same industry M\&A deals. Oztekin and Flannery (2012) conducted a comparative study, which explores the firms' capital structure adjustments and investigated whether a country's financial and legal institutional structures play a role in the adjustment speed. Their sample consisted of 15,177 firms from 37 different countries. The findings showed that the book to leverage adjustment speed was $21.11 \%$ across all the 37 countries and the estimated adjustment speed varied from country to country, starting from $4 \%$ (in Columbia) to $41 \%$ (in New Zealand) per year (Oztekin and Flannery, 2012: 108). Therefore, if a cross border M\&A deal is conducted in a country where the legal and financial institutional structures are effective and ease of doing business is high then the speed of adjustment would also be high. Oztekin and Flannery (2012: 89) explain their findings by stating that the country's legal and financial institutions significantly affect both the costs and the benefits of moving toward target leverage.

Regarding the same industry M\&A, Schwartz and Aronson (1967) state that firms in the same industry have an optimum range in which their capital structure varies. Cross industry M\&A deals diversify the market and expand the customer base of the firms, create a market oriented environment. According to Higgins and Schall (1975), the bankruptcy cost decreases in the cross industry M\&A deals due to diverse markets and imperfect correlated cash flows. Mai, Meng and Ye (2017:292) found that high growth rate of GDP per capita and market oriented environment increase the firm's speed of adjustment toward target capital structure. Cross industry M\&A deals diversify the customer base and increase the economic activities leading to more cash flows as compared to same industry M\&A deals (Mueller, 1977; Amihud, 1981). Diverse markets and cash flows will provide a better 
chance to adjust quickly to their target capital structures for the firms engaged in cross industry M\&A deals compared to the firms engaged in the same industry M\&A deals.

Different studies illustrate that firms adjust toward a target leverage (Taggart, 1977; Marsh, 1982; Auerbach, 1985; Jalilvand and Harris, 1984; Opler and Titman, 1994), but the speed of adjustment may vary between same industry and cross industry or same region and cross border $M \& A$ deals. The findings of the related literature, in respect of the speed of adjustment rate could be divided into two parts, i) fast speed of adjustment, and, ii) slow speed of adjustment. Jalilvand and Harris (1984), Leary and Roberts (2005), Flannery and Rangan (2006), Harford, Sandy and Nathan (2009), Cook and Tang (2010) and Oztekin and Flannery (2012) reported a fast speed of adjustment, while Fama and French (2002), Kayhan and Titman (2007), Qian, Tian and Wirjanto (2009), Huang and Ritter (2009) found that firms adjust slowly toward the target leverage level. Cook and Tang (2010) and Oztekin and Flannery (2012) suggest that macroeconomic conditions such as better legal and financial regulations would lead to faster speed of adjustment due to lower transaction costs.

In light of the above explanations, this study aims to investigate: i) the SOA difference between non-cross border and cross border M\&A deals, ii) the SOA difference between same industry and cross industry M\&A deals, and, iii) to compare SOA of cross border (non-cross border) and cross industry (same industry) M\&A deals. The sample period of this study is 2000 to 2016. The sample of the study consists of 6,520 non-financial firms engaged in M\&A deals globally. The book leverage (BLEV) and market leverage (MLEV) are used as measures of leverage in the analysis. The findings of the study show that the SOA toward target leverage for both BLEV and MLEV is higher in the cross border than in non-cross border M\&A deals. On the other hand, the firms engaged in same industry M\&A move toward the target BLEV and MLEV almost at the same speed as the ones in cross industry M\&A. The study aims to contribute to the SOA and capital structure literature in the area of M\&A by being one of the pioneering studies that explore the SOA in the area of cross border and cross industry M\&A.

The remainder of the paper is organized as follows: section 2, provides the hypotheses of the study, section 3, discusses the sample and methodology, section 4 presents the empirical results. The conclusion is presented in section 5.

\section{HYPOTHESES}

The speed of adjustment across the border and among different industries varies depending on the firm's internal and external characteristics. As discussed earlier, Oztekin and Flannery (2012) state that the speed of adjustment of a firm toward capital structure varies across different countries. Different studies investigating different country firms have also found different speeds of adjustment. Some studies report a fast speed of adjustment (Cook and Tang, 2010; Flannery and Rangan, 2006; Harford, Sandy and Nathan, 2009; Jalilvand and Harris, 1984; Leary and Roberts, 2005; and Oztekin and Flannery, 2012), while in contrast other studies reported a slow speed of adjustment (Fama and French, 2002; Huang and Ritter, 2009; Kayhan and Titman, 2007; Qian, Tian and Wirjanto, 2009).

Oztekin and Flannery (2012) found that SOA varies across different countries where the countries with strong financial and legal institutions have a faster SOA compared to weak institutions. These institutions significantly influence both costs and the benefits of moving toward target leverage. Hence it can be inferred that the SOA in post-M\&A may vary when firms make cross border and cross industry M\&A deals. This also leads to the first hypothesis, that is:

H1: The speed of adjustment is higher in cross border than non-cross border M\&A deals.

Along the same lines, the SOA of same industry and cross industry M\&A deals may differ from each other. According to the literature, cross industry M\&A deals widen the target market, may create imperfectly correlated cash flows, which will reduce bankruptcy costs and will help in making changes in the capital structure (Higgins and Schall, 1975; Ghosh and Jain, 2000). According to Mai et al. (2017), firms having a market orientation environment and surrounded with better economic conditions move faster toward the target capital structure. Same industry M\&A deals have an optimum range in which their capital structure varies (Schwartz and Aronson, 1967). Also, if diverted from their target capital structure, firms will move slower because of the less diversified market as compared to cross industry firms (Mueller, 1977; Amihud, 1981). Therefore, the second hypothesis of the study is that firms engaged in cross industry M\&A deals will move faster than firms in same industry M\&A deals. This leads to the second hypothesis, that is:

H2: The speed of adjustment is lower in same industry than cross industry M\&A deals.

In the first two hypothesis the SOA of the financial leverage is tested across different M\&A cases. For example, the BLEV is tested for non-cross border and cross border deals; similarly MLEV is compared for non-cross and cross border. This is extended to test the BLEV and MLEV adjustment rate for same versus cross industry M\&A deals also. In the first two hypotheses, it is

DOI: 10.17261/Pressacademia.2019.1014 40 
argued that the SOA is slower toward target adjustment for non-cross border and same industry deals as compared to cross border and cross industry. On the other hand, the SOA literature argues that the MLEV has more strength and capture the monetary value not just the assets in place, while BLEV has limited association (Borio, 1990; Harford et al., 2009). Therefore, the SOA rate for the BLEV and MLEV for the same M\&A deals would be different and would have a difference gap. In addition to the above hypotheses, the SOA for BLEV and MLEV is also compared for the same M\&A deals. For example, the SOA difference of BLEV and MLEV is analyzed for non-cross border, cross border, same industry and cross industry M\&A deals separately. The difference gap of BLEV and MLEV is compared between non-cross border and same industry as well as cross border and cross industry. Therefore, based on the discussion four different hypotheses are developed as follows:

H3: There exists a difference between SOA for BLEV and MLEV for non-cross border deals.

H4: There exists difference between SOA for BLEV and MLEV for cross border deals.

H5: There exist difference between SOA for BLEV and MLEV for same industry deals.

H6: There exist difference between SOA for BLEV and MLEV for cross industry deals.

\section{SAMPLE DATA AND METHODOLOGY}

Two types of data were required for this research; firstly, the M\&A cases data and secondly, the financial data. The M\&A cases data was taken from Securities Data Corporation (SDC), the sample period for the M\&A was from 2003 to 2013 . The financial data sample period starts from 2000 to 2016 because three year pre and post financial data is required for the analysis. When determining which M\&A deal to include in the sample, the following were considered: $i)$ the announcement date and effective date of the deal to be in the same year, and, ii) both the acquirer and target firms to be public non-financial firms. There were 19,140 M\&A deals that satisfied these criteria. The financial data was collected from DataStream from Thomson One database. There were wide ranges of missing values and outliers, after cleaning the dataset, the M\&A cases left totaled 6,520.

The total number of firm year observations is 45,640 . For each firm 7 years of financial data is obtained; the event year, in which the deal took place and 3 years pre and post financial data as shown in Figure 1.

Figure 1: Classification of Data for the Study

\begin{tabular}{lll}
$\begin{array}{l}\text { Pre-3 years } \\
\text { financial data }\end{array}$ & $\begin{array}{l}\text { Event year } \\
\mathrm{M}=-3\end{array}$ & $\begin{array}{l}\text { Post-3 years } \\
\text { financial data }\end{array}$ \\
\hline
\end{tabular}

\subsection{Modeling the Speed of Adjustment toward Target Capital Structure}

In a frictionless world, the firms would always be maintaining their target capital structure. However, in the real world, mostly different adjustment costs prevent the firms from adjusting to their target capital structures (Altinkilic and Hansen, 2000; Faulkender et al., 2012; Zhou et al., 2016). In the literature, different procedures are used to measure the incompleteness or partial adjustment toward target capital structure based on different methods (Rajan and Zingales, 1995; Hovakimian et al., 2001; Fama and French, 2002; Flannery and Rangan, 2006; Kayhan and Titman, 2007; Byoun, 2008; Öztekin and Flannery, 2012; Warr et al., 2012). The speed of adjustment model of the present study is constructed in two stages. In the first-stage the target capital structure is estimated, while in the second stage the speed of adjustment is estimated using the target capital structure that is estimated in the first stage. In this study, Flannery and Rangan (2006) SOA model is adopted where they use the market to debt ratio as their primary leverage measure. However, different than their study, in this study both book leverage (BLEV) and market leverage (MLEV) ratios are used as leverage measures.

The SOA model is explained in detail in this section. The standard model of speed of adjustment is provided in equation (1):

$$
B L E V_{i, t+1}-B L E V_{i, t}=\lambda\left(B L E V_{i, t+1}^{*}-B L E V_{i, t}\right)+\varepsilon_{i, t+1}
$$


where $B L E V_{i, t}$ and $B L E V_{i, t+1}$ are the firms debt to book value of total assets for firm $i$ at time $t$ and $t+1$, respectively. $B L E V_{i, t}$ is measured as shown in equation (2),

$$
B L E V_{i, t}=\frac{\left(\text { Long-term debt }_{i, t}+\text { Short-term debt }_{i, t}\right)}{\text { Total assets }_{i, t}}
$$

In equation (1), the " $\lambda$ " estimates the average speed of adjustment to the target level. Each year the firm closes the gap between the actual and the desired leverage level. The equation regresses the change in the actual debt to book value of total assets ratio $\left(B L E V_{i, t+1}-B L E V_{i, t}\right)$ and the change in the expected debt to book value of total assets ratio $\left(B L E V_{i, t+1}^{*}-B L E V_{i, t}\right)$. If the firms adjust their leverage to their target level completely the value of the coefficient $\lambda$ will be 1 . On the other hand, if the firm does not adjust its leverage level then the coefficient $\lambda$ will be zero. The value of coefficient may also move above the value " 1 ", if the firm moves above the target leverage level. In contrast, it will move below the value " 0 " if the firm diverts in the opposite direction from the target leverage value and lower than the pre-M\&A leverage level.

Similarly, the speed of adjustment model for the market leverage is as follows.

$$
M L E V_{i, t+1}-M L E V_{i, t}=\lambda\left(M L E V_{i, t+1}^{*}-M L E V_{i, t}\right)+\varepsilon_{i, t+1}
$$

Where $M_{L E V}$ and $M L E V_{i, t+1}$ are the firms market leverage for firm $i$ at time $t$ and $t+1$, respectively. $M L E V_{i, t}$ is measured as shown in equation (4),

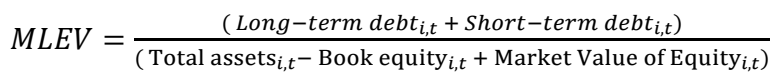

In equation (3), the actual change in $M L E V$ from time $t$ to $t+1$ is regressed with the difference between the target market leverage, $M L E V^{*}$, at time $t+1$ and market leverage, $M L E V$, at time $t$. The speed of adjustment is determined by the coefficient $\lambda$ as explained above.

In both equations (1) and (3), the target book leverage, $B L E V^{*}$, and target market leverage $M L E V^{*}$, are estimated through equation 5 and 6 , respectively:

$$
B L E V_{i, t+1}^{*}=\beta X_{i, t}
$$

and

$$
M L E V_{i, t+1}^{*}=\beta X_{i, t}
$$

where the $B L E V_{i, t+1}^{*}$ and $M L E V_{i, t+1}^{*}$ are the firms desired book and market debt ratios respectively for firm $i$ at time $t+1$. On the other hand, in equations (5) and (6), the vector $X_{i, t}$ is a set of firm characteristics adapted from the previous studies of Flannery and Rangan (2006), Rajan and Zingales (1995), Hovakimian (2006), Hovakimian et al. (2001), Fama and French (2002), whereas $\beta$ is the coefficient vector.

The construct and possible effects of the variables included in vector " $X$ " are:

\section{i. Profitability: Earnings before Interest and Taxes as a Proportion of Total Assets (EBIT_TA)}

A proxy for profitability, the earnings before interest and taxes as a proportion of total assets (EBIT_TA) is used. This variable is calculated as shown in equation (7).

$E B I T \_T A=\frac{\text { Operating Income }+ \text { Interest and Related Expense }+ \text { Current Income Taxes }}{\text { Total Assets }}$

If the firms with high profitability, EBIT_TA ratio, prefer higher leverage to operate with relatively high cash flows, the firm might reflect and signal a stable financial status maintaining the ability to meet debt payments (Flannery \& Rangan, 2006). On the other hand, if they prefer lower leverage, it might be a result of higher retained earnings which mechanically reduce the chance of taking debt (Asgharian, 1997).

\section{ii. Growth Opportunities: Market to book ratio of assets (MB)}

The market to book ratio of assets variable is a measure used to determine the growth opportunities of a firm (Hovakimian et al., 2004; Baker and Wurgler, 2002; Flannery \& Rangan, 2006). It is calculated as in equation (8). 


$$
M B=\frac{\text { Long-term debt }+ \text { Short-term debt }+ \text { Preferred capital }+ \text { Market Value of Equity }}{\text { Total assets }}
$$

Higher market to book ratio sends a positive signal to the market that more attractive future growth options are awaiting. Mixed evidence regarding the relationship between growth opportunities and leverage are found in the literature (Myers, 1977; Rajan and Zingales, 1995; Mittoo and Zhang, 2008). Firms face difficulties to access new external financing during their earlier growth stages, therefore they are forced to use retained earnings. Also, high debt levels put the future profitable investment opportunities at risk and increase the bankruptcy costs. As discussed earlier, to provide a positive signal to the market, limiting leverage is a trend adopted by firms to portray a higher MB.

\section{iii. Nondebt Tax Shield: Depreciation as a proportion of total assets (DEP_TA)}

Following Fama and French (2002), the nondebt tax shield is proxied by DEP_TA which is calculated as in equation (9).

$$
\text { DEP_TA }=\frac{\text { Total Depreciation and Amortization }}{\text { Total assets }}
$$

Depreciation expense also works as a substitute to interest for tax shield. If the level of depreciation expenses are high then it may reduce the need for debt finance to create a tax shield (Antoniou et al., 2008; Flannery \& Rangan, 2006).

\section{iv. Firm Size: Log of total assets (LnTA)}

Firm size is measured by natural logarithm of total assets as shown in equation (10).

$$
\text { LnTA }=\text { Log Total assets }
$$

Larger firms having large amounts of total assets are assumed to be highly diversified with less volatile earnings, hence have low default risk and stable cash flows (Hovakimian et al., 2001). As a proxy of diversification and default risk, firm size is expected to have a positive relationship with leverage ratio (Rajan and Zingales, 1995; Flannery and Rangan, 2006).

\section{v. Tangibility: Fixed assets as a proportion of total assets (FA_TA)}

Tangibility is measured by the percentage of fixed assets in total assets as shown in equation (11).

$$
\text { FA_TA }=\frac{\text { Fixed assets }}{\text { Total assets }}
$$

Firms with greater tangible assets possess a capacity for higher debt (Jensen and Meckling, 1976; Rajan and Zingales, 1995). Firms with more fixed assets are normally larger firms; hence the risk of bankruptcy is reduced (Hovakimian et al., 2001; Flannery and Rangan, 2006). In the event of bankruptcy, the tangible assets are easy to collateralize which lead to a smaller loss in value compared to intangible assets.

\section{vi. Intangibility: Research and development expenses as a proportion of total assets (R\&D_TA)}

The intangible assets of the firm is measured by the R\&D_TA variable, which is calculated as in equation (12).

$$
\text { R\&D_TA }=\frac{\text { Research and Development Expense }}{\text { Total assets }}
$$

Firms with higher proportion of intangible assets in the form of R\&D expenses will prefer to operate with more equity and thus a lower debt ratio (Flannery and Rangan, 2006). According to Uysal (2011:606) firms with higher R\&D expenses tend to have higher growth opportunities and are expected to have low leverage. Bankruptcy cost is also expected to be higher for firms with high R\&D expenses which also lower the chance of getting debt financing (Titman, 1984; Titman and Wessels, 1988).

\section{Vii. Research and development dummy variable (R\&D_DUM)}

A dummy variable for the existence of R\&D activities is included. The R\&D_DUM variable takes a value equal to one for firms that have not reported any R\&D expense and zero for firms that have reported R\&D expense in their financial statements. In contrast, R\&D_TA variable takes the value zero if the firm did not report any R\&D expense (Flannery and Rangan, 2006). The reason of the dummy variable is to differentiate the firms that have not reported any R\&D expense since these firms are likely 
to have made no R\&D expense. Firms with high R\&D expense are expected to have less debt so firms having no R\&D expense would be expected to have higher leverage. Thus, the dummy variable is expected to have a positive sign.

\section{viii. Industry median (IND_MED) of debt ratio}

The industry median debt ratio is included to capture the industry characteristics that may not be captured by other explanatory variables (Flannery and Rangan, 2006). In the literature, it is found that the level of target leverage ratio is dependent on the industries the firms operate in (Smith, Chen and Anderson, 2015; Stoja and Tucker, 2007). The classification of the industries was based on the Fama and French (1997) industry definitions.

In Table 1 the descriptive statistics of all variables are presented. There are 45,640 firm years' observations consisting of 6,520 non-financial acquiring firms and 7 years financial data.

\section{Table 1: Descriptive statistics}

Sample includes all nonfinancial acquiring firms with complete data starting from year 2000 to 2016. Each firm's 7 years of financial data is retrieved, Total: 6,520 firms and 45640 firm years Observations

\begin{tabular}{llllll}
\hline & Mean & Median & Maximum & Minimum & Std. Dev. \\
\hline BLEV & 0.1644 & 0.1376 & 0.9137 & 0.0000 & 0.1528 \\
MLEV & 0.1199 & 0.0816 & 0.9136 & 0.0000 & 0.1304 \\
EBIT_TA & 0.0451 & 0.0708 & 4.1823 & -17.0152 & 0.2826 \\
MB & 1.7666 & 1.1848 & 64.4936 & 0.0001 & 2.4319 \\
DEP_TA & 0.1505 & 0.1169 & 0.8926 & 0.0000 & 0.1224 \\
LNTA & 20.2208 & 20.1659 & 27.4051 & 11.4080 & 2.2776 \\
FA_TA & 0.3313 & 0.2747 & 0.9890 & 0.0001 & 0.2382 \\
RD_TA & 0.0259 & 0.0000 & 0.9484 & 0.0000 & 0.0634 \\
RD_DUM & 0.6384 & 1.0000 & 1.0000 & 0.0000 & 0.4805 \\
IND_MED_BLEV & 0.1568 & 0.1376 & 0.8578 & 0.0000 & 0.1337 \\
IND_MED_MLEV & 0.1130 & 0.0818 & 0.9136 & 0.0000 & 0.1158 \\
\hline
\end{tabular}

\section{EMPIRICAL FINDINGS}

In this section the empirical findings are reported for both the cross border and cross industry M\&A cases. In the first part of the empirical findings, the results of the analysis of the target book leverage (BLEV*) of both cross border and cross industry cases are discussed. While in the second part the target market leverage $\left(\mathrm{MLEV}^{*}\right)$ results of cross border and cross industry cases are presented.

Table 2 displays the regression estimators for target book leverage (BLEV*) for both cross border and cross industry M\&A cases. Column (1) presents the estimators for the non-cross border M\&A, column (2) presents the cross border M\&A, column (3) presents estimators for the same industry M\&A and column (4) presents the cross industry M\&A. The fixed effects regression model is suggested by Hausman test for all the four different M\&A cases. The results show that EBIT_TA and DEP_TA variables are negatively significantly associated with the BLEV in all four cases. All the other variables are positively significantly related with BLEV except RD_TA dummy variable. The RD_TA variable is positively associated with BLEV in the cross border (column 3 ) M\&A deals but the relationship is found to be statistically not significant. The magnitude of the coefficient of IND_MED is the highest compared to the other variables.

It shows that if 1 percent change appeared in IND_MED it will increase the BLEV by $83.60 \%, 89.65 \%, 83.95 \%$ and $86.68 \%$ in noncross border, cross border, same industry and cross industry M\&A, respectively. The F-statistic is significant and $R$ square is 91.7\% for non-cross border, $95.0 \%$ for cross border, $92.1 \%$ and $93.2 \%$ for same industry and cross industry respectively. The high R-square values may be due to the high number of firm year observations. High R-square values are also reported in similar SOA studies in literature (Cook and Tang, 2010). 


\section{Table 2: Target Capital Regression Estimators for BLEV* for Cross Borders and Cross Industry M\&A Cases}

The target book leverage (BLEV*) estimator are displayed here. The column (1) presents the BLEV* estimators for the non-cross border M\&A, column (2) presents the cross border M\&A, column (3) presents the BLEV* estimators for the same industry M\&A and column (4) presents the cross industry M\&A. The measurement of variables are (i) EBIT_TA=(Operating Income + Interest and related expense + Current Income Taxes)/(Total assets), (ii) MB=(Long-term debt +Short-term debt + Preferred capital + Market Value of Equity)/(Total assets), (iii) DEP_TA=(Total Depreciation and Amortization)/(Total assets), (iv) LnTA=Log Total assets, (v) FA_TA=(Fixed assets)/(Total assets), (vi) R\&D_TA=(Research and Development Expense)/(Total assets), (vii) IND_MED: Industry median, (ix) R\&D_DUM: Research and development dummy variable. ${ }^{* * *}, * *$, and * represent significance at the $1 \%$, $5 \%$, and $10 \%$ level, respectively.

\begin{tabular}{|c|c|c|c|c|}
\hline & $\begin{array}{l}\text { Non-cross border } \\
\text { (1) }\end{array}$ & $\begin{array}{l}\text { Cross border } \\
\text { (2) }\end{array}$ & $\begin{array}{l}\text { Same Industry } \\
\text { (3) }\end{array}$ & $\begin{array}{l}\text { Cross Industry } \\
\text { (4) }\end{array}$ \\
\hline INTERCEPT & $\begin{array}{l}-0.231^{* * *} \\
(0.000)\end{array}$ & $\begin{array}{l}-0.0786^{*} \\
(0.094)\end{array}$ & $\begin{array}{l}-0.2348 * * * \\
(0.000)\end{array}$ & $\begin{array}{l}-0.1540 * * * \\
(0.000)\end{array}$ \\
\hline EBIT_TA & $\begin{array}{l}-0.007^{* *} \\
(0.022)\end{array}$ & $\begin{array}{l}-0.0111^{* *} \\
(0.026)\end{array}$ & $\begin{array}{l}-0.0123 * * \\
(0.019)\end{array}$ & $\begin{array}{l}-0.0052^{*} \\
(0.081)\end{array}$ \\
\hline $\mathrm{MB}$ & $\begin{array}{l}0.001 * * * \\
(0.000)\end{array}$ & $\begin{array}{l}0.0005^{*} \\
(0.089)\end{array}$ & $\begin{array}{l}0.0020^{* * *} \\
(0.000)\end{array}$ & $\begin{array}{l}0.0005^{*} \\
(0.078)\end{array}$ \\
\hline DEP_TA & $\begin{array}{l}-0.056^{* * *} \\
(0.005)\end{array}$ & $\begin{array}{l}-0.1517^{* * *} \\
(0.000)\end{array}$ & $\begin{array}{l}-0.0801 * * * \\
(0.001)\end{array}$ & $\begin{array}{l}-0.0839 * * * \\
(0.000)\end{array}$ \\
\hline LNTA & $\begin{array}{l}0.012 * * * \\
(0.000)\end{array}$ & $\begin{array}{l}0.0049 * * \\
(0.025)\end{array}$ & $\begin{array}{l}0.0131 * * * \\
(0.000)\end{array}$ & $\begin{array}{l}0.0081 * * * \\
(0.000)\end{array}$ \\
\hline FA_TA & $\begin{array}{l}0.054^{* * *} \\
(0.000)\end{array}$ & $\begin{array}{l}0.0722 * * * \\
(0.000)\end{array}$ & $\begin{array}{l}0.0389 * * * \\
(0.003)\end{array}$ & $\begin{array}{l}0.0751 * * * \\
(0.000)\end{array}$ \\
\hline RD_TA & $\begin{array}{l}0.164^{* * * *} \\
(0.000)\end{array}$ & $\begin{array}{l}0.026 \\
(0.303)\end{array}$ & $\begin{array}{l}0.1077^{* * *} \\
(0.000)\end{array}$ & $\begin{array}{l}0.1361^{* * *} \\
(0.000)\end{array}$ \\
\hline IND_MED & $\begin{array}{l}0.8360 * * * \\
(0.000)\end{array}$ & $\begin{array}{l}0.8965^{* * *} \\
(0.000)\end{array}$ & $\begin{array}{l}0.8395^{* * *} \\
(0.000)\end{array}$ & $\begin{array}{l}0.8668^{* * *} \\
(0.000)\end{array}$ \\
\hline RD_TA_DUM & $\begin{array}{l}0.005 \\
(0.247)\end{array}$ & $\begin{array}{l}-0.0014 \\
(0.783)\end{array}$ & $\begin{array}{l}0.0032 \\
(0.570)\end{array}$ & $\begin{array}{l}0.0035 \\
(0.439)\end{array}$ \\
\hline Fixed effect & Yes & Yes & Yes & Yes \\
\hline Observations & 13095 & 6465 & 9042 & 10518 \\
\hline R-squared & 0.917 & 0.950 & 0.921 & 0.932 \\
\hline $\mathrm{F}$ & $\begin{array}{l}22.025^{* * *} \\
(0.000)\end{array}$ & $\begin{array}{l}37.966^{* * *} \\
(0.000)\end{array}$ & $\begin{array}{l}23.482^{* * *} \\
(0.000)\end{array}$ & $\begin{array}{l}27.433 * * * \\
(0.000)\end{array}$ \\
\hline
\end{tabular}

Table 3 shows the estimators of target market leverage (MLEV*) for all the four types of M\&A cases. The table exhibits that in all the four M\&A cases the IND MED has the highest positive significant association with MLEV. The MB has the lowest significant association with MLEV. The variable EBIT_TA, MB and DEP_TA are significantly negatively associated with MLEV in all the four cases. The RD_TA dummy and RD_TA variable coefficient are non-significant in all the cases except non-cross border M\&A cases where RD_TA is significant at $10 \%$. Three variables including LNTA, FA_TA and IND_MED are positively significantly associated with the dependent variable MLEV. 


\section{Table 3: Target Capital Regression Estimators for MLEV* for Cross Borders and Cross Industry M\&A Cases}

The target market leverage (MLEV*) estimator are displayed here. The column (1) presents the MLEV* estimators for the noncross border M\&A, column (2) presents the cross borders M\&A, column (3) presents the MLEV* estimators for the same industry M\&A and column (4) presents the cross industry M\&A. The measurement of variables are (i) EBIT_TA=(Operating Income + Interest and related expense + Current Income Taxes)/(Total assets), (ii) MB=(Long-term debt +Short-term debt + Preferred capital + Market Value of Equity)/(Total assets), (iii) DEP_TA=(Total Depreciation and Amortization)/(Total assets), (iv) LnTA=Log Total assets, (v) FA_TA=(Fixed assets)/(Total assets), (vi) R\&D_TA=(Research and Development Expense)/(Total assets), (vii) IND_MED: Industry median, (ix) R\&D_DUM: Research and development dummy variable. $* * *, * *$, and $*$ represent significance at the $1 \%, 5 \%$, and $10 \%$ level, respectively.

\begin{tabular}{|c|c|c|c|c|}
\hline & $\begin{array}{l}\text { Non-cross borders } \\
\text { (1) }\end{array}$ & $\begin{array}{l}\text { Cross borders } \\
\text { (2) }\end{array}$ & $\begin{array}{l}\text { Same Industry } \\
\text { (3) }\end{array}$ & $\begin{array}{l}\text { Cross Industry } \\
\text { (4) }\end{array}$ \\
\hline INTERCEPT & $\begin{array}{l}-0.2785^{* * *} \\
(0.000)\end{array}$ & $\begin{array}{l}-0.1790 * * * \\
(0.000)\end{array}$ & $\begin{array}{l}-0.2727^{* * *} \\
(0.000)\end{array}$ & $\begin{array}{l}-0.2416^{* * * *} \\
(0.000)\end{array}$ \\
\hline EBIT_TA & $\begin{array}{l}-0.0075^{* * *} \\
(0.002)\end{array}$ & $\begin{array}{l}-0.0159 * * * \\
(0.000)\end{array}$ & $\begin{array}{l}-0.0184 * * * \\
(0.000)\end{array}$ & $\begin{array}{l}-0.0056^{* *} \\
(0.015)\end{array}$ \\
\hline $\mathrm{MB}$ & $\begin{array}{l}-0.0011^{* * *} \\
(0.000)\end{array}$ & $\begin{array}{l}-0.0005^{* *} \\
(0.036)\end{array}$ & $\begin{array}{l}-0.0009 * * * \\
(0.000)\end{array}$ & $\begin{array}{l}-0.0011^{* * *} \\
(0.000)\end{array}$ \\
\hline DEP_TA & $\begin{array}{l}-0.1162^{* * *} \\
(0.000)\end{array}$ & $\begin{array}{l}-0.0833^{* * *} \\
(0.000)\end{array}$ & $\begin{array}{l}-0.0783^{* * *} \\
(0.000)\end{array}$ & $\begin{array}{l}-0.1526 * * * \\
(0.000)\end{array}$ \\
\hline LNTA & $\begin{array}{l}0.0155^{* * *} \\
(0.000)\end{array}$ & $\begin{array}{l}0.0100 * * * \\
(0.000)\end{array}$ & $\begin{array}{l}0.0155^{* * *} \\
(0.000)\end{array}$ & $\begin{array}{l}0.0130 * * * \\
(0.000)\end{array}$ \\
\hline FA_TA & $\begin{array}{l}0.0608^{* * *} \\
(0.000)\end{array}$ & $\begin{array}{l}0.0320 * * * \\
(0.004)\end{array}$ & $\begin{array}{l}0.0222 * * \\
(0.022)\end{array}$ & $\begin{array}{l}0.0926 * * * \\
(0.000)\end{array}$ \\
\hline RD_TA & $\begin{array}{l}0.0302 * \\
(0.053)\end{array}$ & $\begin{array}{l}0.0008 \\
(0.964)\end{array}$ & $\begin{array}{l}0.0262 \\
(0.155)\end{array}$ & $\begin{array}{l}0.0141 \\
(0.395)\end{array}$ \\
\hline IND_MED & $\begin{array}{l}0.8011^{* * *} \\
(0.000)\end{array}$ & $\begin{array}{l}0.8545^{* * *} \\
(0.000)\end{array}$ & $\begin{array}{l}0.8027^{* * *} \\
(0.000)\end{array}$ & $\begin{array}{l}0.8288^{* * *} \\
(0.000)\end{array}$ \\
\hline RD_TA_DUM & $\begin{array}{l}-0.0005 \\
(0.894)\end{array}$ & $\begin{array}{l}-0.0034 \\
(0.370)\end{array}$ & $\begin{array}{l}-0.0007 \\
(0.869)\end{array}$ & $\begin{array}{l}-0.0024 \\
(0.495)\end{array}$ \\
\hline Fixed effect & Yes & Yes & Yes & Yes \\
\hline Observations & 13095 & 6465 & 9042 & 10518 \\
\hline R-squared & 0.923 & 0.946 & 0.925 & 0.934 \\
\hline $\mathrm{F}$ & $\begin{array}{l}24.018^{* * *} \\
(0.000)\end{array}$ & $\begin{array}{l}34.928 * * * \\
(0.000)\end{array}$ & $\begin{array}{l}24.672 * * * \\
(0.000)\end{array}$ & $\begin{array}{l}27.995 * * * \\
(0.000)\end{array}$ \\
\hline
\end{tabular}

In Table 4, the Speed of Adjustment for the book leverage (BLEV) is displayed for both cross border and cross industry M\&A cases. The table shows that the speed of adjustment (SOA) for non-cross border M\&A cases (33.79\%) is lower than the cross border M\&A cases $(41.40 \%)$. On the other hand, the SOA in the same industry M\&A cases $(35.51 \%)$ compared to the cross industry M\&A cases (36.35\%) is almost the same. The cross industry M\&A deals move almost $0.8 \%$ faster than the same industry M\&A cases. All the values are significant at $1 \%$ level and $R$-square values are lower compared to the previous regression results because of the lower number of observations. 
Table 4: Speed of Adjustment BLEV for Cross Border and Cross Industry M\&A Cases

\begin{tabular}{|c|c|c|c|c|c|c|}
\hline & & $\begin{array}{l}\text { Post 1st } \\
\text { Year }\end{array}$ & $\begin{array}{l}\text { Post 2nd } \\
\text { Year }\end{array}$ & $\begin{array}{l}\text { Post 3rd } \\
\text { Year }\end{array}$ & $\begin{array}{l}\text { Avg SOA } \\
\text { per year }\end{array}$ & No. of Years \\
\hline \multirow{3}{*}{ Non-cross border } & Adj_speed & $\begin{array}{l}0.3864^{* * *} \\
(0.000)\end{array}$ & $\begin{array}{l}0.3426^{* * *} \\
(0.000)\end{array}$ & $\begin{array}{l}0.2848^{* * *} \\
(0.000)\end{array}$ & 0.3379 & 2.9593 \\
\hline & Observations & 4365 & 4365 & 4365 & & \\
\hline & R-squared & 0.274 & 0.243 & 0.189 & & \\
\hline \multirow{3}{*}{ Cross border } & Adj_speed & $\begin{array}{l}0.4303^{* * *} \\
(0.000)\end{array}$ & $\begin{array}{l}0.3978^{* * *} \\
(0.000)\end{array}$ & $\begin{array}{l}0.4140 * * * \\
(0.000)\end{array}$ & 0.4140 & 2.4152 \\
\hline & Observations & 2155 & 2155 & 2155 & & \\
\hline & R-squared & 0.349 & 0.291 & 0.314 & & \\
\hline \multirow{3}{*}{ Same Industry } & Adj_speed & $\begin{array}{l}0.3927^{* * *} \\
(0.000)\end{array}$ & $\begin{array}{l}0.3390^{* * *} \\
(0.000)\end{array}$ & $\begin{array}{l}0.3337^{* * *} \\
(0.000)\end{array}$ & 0.3551 & 2.8161 \\
\hline & Observations & 3014 & 3014 & 3014 & & \\
\hline & R-squared & 0.293 & 0.240 & 0.229 & & \\
\hline \multirow{3}{*}{ Cross Industry } & Adj_speed & $\begin{array}{l}0.4041^{* * *} \\
(0.000)\end{array}$ & $\begin{array}{l}0.3727^{* * *} \\
(0.000)\end{array}$ & $\begin{array}{l}0.3136^{* * *} \\
(0.000)\end{array}$ & 0.3635 & 2.7513 \\
\hline & Observations & 3506 & 3506 & 3506 & & \\
\hline & R-squared & 0.295 & 0.268 & 0.221 & & \\
\hline
\end{tabular}

It could also be observed in Figure-2 (a) and (b), that the average SOA line moves upward in part (a) and is a straight line in part (b). The total number of years for non-cross border M\&A to adjust is 2.959 years while in cross border M\&A cases it will take 2.415 years to adjust to its target BLEV*. In the case of same and cross industry M\&A cases, the adjustment to target BLEV* is 2.816 years and 2.751 years, respectively.

Figure-2: Cross Border and Cross Industry Speed of Adjustment Graph
(a) Non-cross border and cross border, M\&A BLEV* Graph
(b) Same and cross industry M\&A, BLEV* Graph
(c) Non-cross border and cross border M\&A, MLEV* Graph
(d) Same and cross industry M\&A, MLEV* Graph 


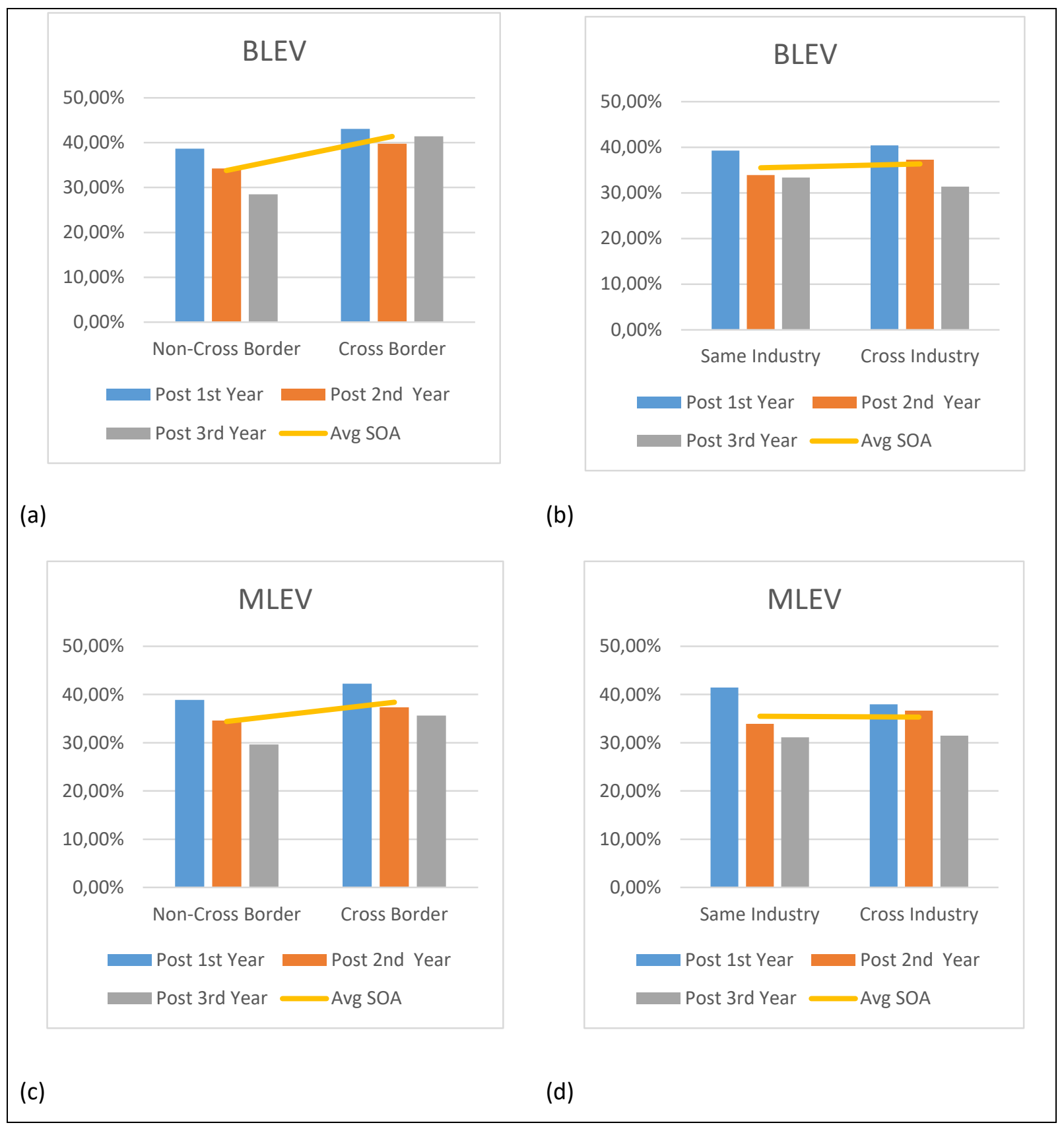

Table 5 shows the SOA for the MLEV for cross border and cross industry M\&A cases. The average SOA is lower in the non-cross border than cross border M\&A cases, which is $34.38 \%$ and $38.39 \%$ per year, respectively. In this regard, it will take approximately around 2.9 and 2.6 years to rebalance to the target capital structure for both non-cross border and cross border M\&A cases, respectively. 
Table 5: Speed of Adjustment MLEV for Cross Border and Cross Industry M\&A Cases

\begin{tabular}{|c|c|c|c|c|c|c|}
\hline & & $\begin{array}{l}\text { Post 1st } \\
\text { Year }\end{array}$ & $\begin{array}{l}\text { Post 2nd } \\
\text { Year }\end{array}$ & $\begin{array}{l}\text { Post 3rd } \\
\text { Year }\end{array}$ & $\begin{array}{l}\text { Avg SOA } \\
\text { per year }\end{array}$ & No. of Years \\
\hline \multirow{3}{*}{ Non-cross border } & Adj_speed & $\begin{array}{l}0.3887^{* * *} \\
(0.000)\end{array}$ & $\begin{array}{l}0.3461^{* * *} \\
(0.000)\end{array}$ & $\begin{array}{l}0.2964 * * * \\
(0.000)\end{array}$ & 0.3438 & 2.9090 \\
\hline & Observations & 4365 & 4365 & 4365 & & \\
\hline & R-squared & 0.279 & 0.240 & 0.203 & & \\
\hline \multirow{3}{*}{ Cross border } & Adj_speed & $\begin{array}{l}0.4223 * * * \\
(0.000)\end{array}$ & $\begin{array}{l}0.3732 * * * \\
(0.000)\end{array}$ & $\begin{array}{l}0.3561^{* * *} \\
(0.000)\end{array}$ & 0.3839 & 2.6051 \\
\hline & Observations & 2155 & 2155 & 2155 & & \\
\hline & R-squared & 0.320 & 0.282 & 0.269 & & \\
\hline \multirow{3}{*}{ Same Industry } & Adj_speed & $\begin{array}{l}0.4142^{* * * *} \\
(0.000)\end{array}$ & $\begin{array}{l}0.3394 * * * \\
(0.000)\end{array}$ & $\begin{array}{l}0.3115^{* * * *} \\
(0.000)\end{array}$ & 0.3550 & 2.8167 \\
\hline & Observations & 3014 & 3014 & 3014 & & \\
\hline & R-squared & 0.308 & 0.246 & 0.212 & & \\
\hline \multirow{3}{*}{ Cross Industry } & Adj_speed & $\begin{array}{l}0.3795 * * * \\
(0.000)\end{array}$ & $\begin{array}{l}0.3663^{* * *} \\
(0.000)\end{array}$ & $\begin{array}{l}0.3144 * * * \\
(0.000)\end{array}$ & 0.3534 & 2.8296 \\
\hline & Observations & 3506 & 3506 & 3506 & & \\
\hline & R-squared & 0.270 & 0.258 & 0.229 & & \\
\hline
\end{tabular}

In the M\&A deals of same industry and cross industry M\&A, the difference between SOA is narrow. The same industry M\&A firms adjust slightly faster than the cross industry M\&A cases when MLEV is included in the model. The SOA is $35.50 \%$ for same industry M\&A and they may adjust to target MLEV in 2.81 years. While in the cross industry M\&A cases, the SOA is $35.34 \%$ and readjustment to target capital structure in 2.83 years. The results of MLEV speed of adjustment analysis are graphically presented in Figure-2, (c) and (d).

From Figure 2(c) it can be observed that the average SOA line have an upward movement from non-cross border to cross border M\&A graph. There is almost $4 \%$ different in the average SOA between non-cross border and cross border M\&A cases. While in part (d) for the same and cross industry M\&A cases, the figure shows that SOA average move in a straight line from the same to cross industry M\&A cases. The difference between the same industry and cross industry for MLEV is approximately $0.2 \%$.

The findings of the study show support for the first hypothesis that the speed for cross border M\&A is higher than the non-cross border M\&A deals. This can be attributed to different countries having different legal and financial structures, which influence the SOA, as also argued by Oztekin and Flannery (2012). If the legal and financial structures are well established, the SOA will be high as compared to weak legal and financial structures. Additionally, literature shows that firms operating in countries having high growth rates of GDP per capita has high SOA rate (Mai et al., 2017). The findings of the present study, provide evidence that the cross border M\&A deals have higher SOA rates compared to non-cross border M\&A deals for both BLEV and MLEV. The reason for this finding can be that the acquiring firm's country may have strong legal and financial structure and better macroeconomic conditions. Hence, the findings of SOA toward target BLEV and MLEV support hypothesis-1 that the SOA is higher in cross border than non-cross border M\&A cases.

Contrarily, the SOA analysis results for same industry and cross industry M\&A cases do not provide supporting evidence to hypothesis 2 . In the BLEV analysis, there is an approximately $0.8 \%$ difference in the SOA for same industry and cross industry $M \& A$ cases. The movement toward target BLEV* in cross industry M\&A cases move slightly faster than same industry M\&A deals. In contrast, for the MLEV analysis, the SOA of same industry is $0.2 \%$ higher than cross industry M\&A cases. This shows that there is mixed results for SOA for the same and cross industry for BLEV and MLEV. Therefore, The second hypothesis that the speed of adjustment is lower in same industry than cross industry M\&A deals, could not be accepted because the SOA is almost the same for both the same and cross industry M\&A deals. 
While comparing the SOA for BLEV and MLEV across the four M\&A cases, it is observed that the SOA rate trend is almost the same for BLEV and MLEV in non-cross border and same industry M\&A cases. For example, for non-cross border M\&A cases the average SOA for BLEV is $33.79 \%$ as shown in Table 4 , while MLEV is $34.38 \%$ as reported in Table 5 , the difference is $0.59 \%$. Similar average SOA pattern is seen for the same industry deals, where BLEV is $35.51 \%$ and MLEV is $35.50 \%$, difference is $0.01 \%$. This result shows that the gap between BLEV and MLEV in non-cross border and same industry M\&A cases is narrow. In contrast the difference in cross border M\&A cases is wider between BLEV and MLEV, in which the BLEV (41.40\%) moves $3.01 \%$ faster toward target capital structure compared to MLEV (38.39\%). On the other hand the gap between BLEV and MLEV in the cross industry M\&A deals also wider. The BLEV adjustment speed is $36.35 \%$ while MLEV is $35.34 \%$, indicating that the BLEV moves $1.01 \%$ faster than MLEV. The results indicate that hypothesis 3 and 5 could not be accepted while hypothesis 4 and 6 may be accepted.

In summary, firstly, the SOA rate for BLEV across the four different M\&A cases was investigated, secondly, the MLEV SOA rate was analyzed, and finally both the BLEV and MLEV were compared across all four M\&A cases. It was found that that the SOA rate for both BLEV and MLEV, non-cross border and cross border M\&A cases had a difference in the speed of adjustment toward target capital structure. In contrast, the SOA rate, comparing the same and cross industry M\&A cases, does not show much difference for BLEV and MLEV. Lastly, the SOA rate difference gap for BLEV and MLEV were almost the same in all M\&A cases except for cross border where the BLEV moved slightly faster than MLEV toward target capital structure. Overall the average SOA rate for BLEV and MLEV are consistent with the findings of Cook and Tang (2010), Flannery and Rangan (2006) Leary and Roberts (2005) and Oztekin and Flannery (2012) studies which consider it as a fast speed of adjustment.

\section{CONCLUSION}

In this study, the capital structure and adjustment to target capital structure in cross border and cross industry M\&A were investigated. The sample consisted of 6,520 M\&A deals for the period of 2000 to 2016. The book leverage and market leverage were used in the analysis. The findings of the study support the arguments that in the cross border M\&A deals, capital structures are adjusted faster than the non-cross border deals. While the same industry M\&A deals and cross industry M\&A deals experience almost the same SOA rate for both BLEV and MLEV. The findings of the study also illustrate that the SOA for the BLEV and MLEV for all the four different M\&A cases remained almost the same. The study provided evidence that the firms adjust their capital structure toward their pre-M\&A level in approximately 3 years.

As this study compared the SOA of cross border and cross industry M\&A deals, many avenues for future research remain open in the area of SOA and M\&A. For future research, it will be of special interest if the same and cross industry deals could be investigated for cross border M\&A deals. This study contributed to the literature of SOA toward target capital in the area of $M \& A$, which has not been explored before.

\section{REFERENCES}

Altinkilic, O., Hansen, R. S. (2000). Are there economies of scale in underwriting fees? Evidence of rising external financing costs. The Review of Financial Studies, 13(1), 191-218.

Amihud, Y., Lev, B. (1981). Risk reduction as a managerial motive for conglomerate mergers. The Bell Journal of Economics, $12(2) 605-617$.

Antoniou, A., Guney, Y., Paudyal, K. (2008). The determinants of capital structure: capital market-oriented versus bank-oriented institutions. Journal of Financial and Quantitative Analysis, 43(1), 59-92.

Auerbach, A. J. (1985). The theory of excess burden and optimal taxation. In Handbook of Public Economics. Elsevier Science Publishers. 1, 61127.

Baker, M., Wurgler, J., (2002). Market timing and capital structure. The Journal of Finance 57, 1-32.

Borio, C. E. V. (1990). Leverage and financing of non-financial companies: an international perspective. Bank for International Settlements (BIS), Economic Papers No. 27, 1-82.

Byoun, S. (2008). How and when do firms adjust their capital structures toward targets?. The Journal of Finance, 63(6), 3069-3096.

Cook, D. O., Tang, T. (2010). Macroeconomic conditions and capital structure adjustment speed. Journal of Corporate Finance, $16(1)$, $73-87$.

Fama, E. F., French, K. R. (1997). Industry costs of equity. Journal of Financial Economics, 43(2), 153-193.

DOI: 10.17261/Pressacademia.2019.1014 50 
Fama, E. F., French, K. R. (2002). Testing trade-off and pecking order predictions about dividends and debt. The Review of Financial Studies, 15(1), 1-33.

Faulkender, M., Flannery, M. J., Hankins, K. W., Smith, J. M. (2012). Cash flows and leverage adjustments. Journal of Financial Economics, 103(3), 632-646.

Faulkender, M., Kadyrzhanova, D., Prabhala, N., Senbet, L. (2010). Executive compensation: An overview of research on corporate practices and proposed reforms. Journal of Applied Corporate Finance, 22(1), 107-118.

Fischer, E. O., Heinkel, R., Zechner, J. (1989). Dynamic capital structure choice: Theory and tests. The Journal of Finance, 44(1), 19-40.

Flannery, M. J., Rangan, K. P. (2006). Partial adjustment toward target capital structures. Journal of Financial Economics, 79(3), 469-506.

Ghosh, A., Jain, P. C. (2000). Financial leverage changes associated with corporate mergers. Journal of Corporate Finance, 6(4), 377-402.

Graham, J. R., Harvey, C. R. (2001). The theory and practice of corporate finance: Evidence from the field. Journal of Financial Economics, 60(23), $187-243$.

Gugler, K., Konrad, K. A. (2002). Merger target selection and financial structure. University of Vienna and Wissenschaftszentrum Berlin (WZB).

Harford, J. (2005). What drives merger waves?. Journal of Financial Economics, 77(3), 529-560.

Harford, J., Klasa, S., Walcott, N. (2009). Do firms have leverage targets? Evidence from acquisitions. Journal of Financial Economics, 93(1), 1-14.

Higgins, R. C., Schall, L. D. (1975). Corporate bankruptcy and conglomerate merger. The Journal of Finance, 30(1), 93-113.

Hovakimian, A. (2006). Are observed capital structures determined by equity market timing?. Journal of Financial and Quantitative Analysis, $41(1), 221-243$.

Hovakimian, A., Hovakimian, G., Tehranian, H. (2004). Determinants of target capital structure: The case of dual debt and equity issues. Journal of Financial Economics, 71(3), 517-540.

Hovakimian, A., Opler, T., Titman, S. (2001). The debt-equity choice. Journal of Financial and Quantitative Analysis, 36(1), 1-24.

Huang, R., Ritter, J. R. (2009). Testing theories of capital structure and estimating the speed of adjustment. Journal of Financial and Quantitative Analysis, 44(2), 237-271.

Jalilvand, A., Harris, R. S. (1984). Corporate behavior in adjusting to capital structure and dividend targets: An econometric study. The Journal of Finance, 39(1), 127-145.

Jarrell, G. A., Brickley, J. A., Netter, J. M. (1988). The market for corporate control: The empirical evidence since 1980. Journal of Economic Perspectives, 2(1), 49-68.

Jensen, M. C., Meckling, W. H. (1976). Theory of the firm: Managerial behavior, agency costs and ownership structure. Journal of Financial Economics, 3(4), 305-360.

Kayhan, A., Titman, S. (2007). Firms' histories and their capital structures. Journal of Financial Economics, 83(1), 1-32.

Leary, M. T., Roberts, M. R. (2005). Do firms rebalance their capital structures?. The Journal of Finance, 60(6), 2575-2619.

Leland, H. E. (2007). Financial synergies and the optimal scope of the firm: Implications for mergers, spinoffs, and structured finance. The Journal of Finance, 62(2), 765-807.

Lewellen, W. G. (1971). A pure financial rationale for the conglomerate merger. The Journal of Finance, 26(2), 521-537.

Lintner, J. (1971). Expectations, mergers and equilibrium in purely competitive securities markets. The American Economic Review, 61(2), 101111.

Mai, Y., Meng, L., Ye, Z. (2017). Regional variation in the capital structure adjustment speed of listed firms: Evidence from China. Economic Modelling, 64, 288-294.

Markham, J. W. (1973). Conglomerate Enterprise and Economic Performance. Cambridge, MA: Harvard University Press.

Marsh, P. (1982). The choice between equity and debt: An empirical study. The Journal of Finance, 37(1), 121-144.

Mitchell, M., Mulherin, H., 1996. The impact of industry shocks on takeover and restructuring activity. Journal of Financial Economics $41,193-$ 230.

Mittoo, U. R., Zhang, Z. (2008). The capital structure of multinational corporations: Canadian versus US evidence. Journal of Corporate Finance, 14(5), 706-720. 
Moatti, V., Ren, C. R., Anand, J., Dussauge, P. (2015). Disentangling the performance effects of efficiency and bargaining power in horizontal growth strategies: An empirical investigation in the global retail industry. Strategic Management Journal, 36(5), 745-757.

Modigliani, F., Miller, M. H. (1963). Corporate income taxes and the cost of capital: a correction. The American Economic Review, 53(3), 433443.

Mueller, D. C. (1977). The effects of conglomerate mergers: A survey of the empirical evidence. Journal of Banking \& Finance, 1(4), 315-347.

Myers, S. C. (1977). Determinants of corporate borrowing. Journal of Financial Economics, 5(2), 147-175.

Myers, S. C. (1984). The capital structure puzzle. The Journal of Finance, 39(3), 574-592.

Opler, T. C., Titman, S. (1994). Financial distress and corporate performance. The Journal of Finance, 49(3), 1015-1040.

Oztekin, O., Flannery, M. J. (2012). Institutional determinants of capital structure adjustment speeds. Journal of Financial Economics, 103(1), 88112.

Qian, Y., Tian, Y., Wirjanto, T. S. (2009). Do Chinese publicly listed companies adjust their capital structure toward a target level?. China Economic Review, 20(4), 662-676.

Rajan, R. G., Zingales, L. (1995). What do we know about capital structure? Some evidence from international data. The Journal of Finance, 50(5), 1421-1460.

Ross, S. A. (1977). The determination of financial structure: the incentive-signalling approach. The Bell Journal of Economics, 23-40.

Schwartz, E., Aronson, J. R. (1967). Some surrogate evidence in support of the concept of optimal financial structure. The Journal of Finance, 22(1), 10-18.

Scott, J. H. (1977). On the theory of conglomerate mergers. The Journal of Finance, 32(4), 1235-1250.

Shyam-Sunder, L., Myers, S. C. (1999). Testing static tradeoff against pecking order models of capital structure. Journal of Financial Economics, 51(2), 219-244.

Smith, D. J., Chen, J., Anderson, H. D. (2015). The influence of firm financial position and industry characteristics on capital structure adjustment. Accounting \& Finance, 55(4), 1135-1169.

Staikouras, S. K. (2006). Business opportunities and market realities in financial conglomerates. The Geneva Papers on Risk and Insurance-Issues and Practice, 31(1), 124-148.

Stoja, E., Tucker, J. (2007). Long and short-run capital structure dynamics in the UK-an industry level study. SSRN Electronic Journal. $10.2139 /$ ssrn.1045101

Stulz, R. (1990). Managerial discretion and optimal financing policies. Journal of Financial Economics, 26(1), 3-27.

Taggart Jr, R. A. (1977). A model of corporate financing decisions. The Journal of Finance, 32(5), 1467-1484.

Titman, S. (1984). The effect of capital structure on a firm's liquidation decision. Journal of Financial Economics, 13(1), 137-151.

Titman, S., Wessels, R. (1988). The determinants of capital structure choice. The Journal of Finance, 43(1), 1-19.

Uysal, V. B. (2011). Deviation from the target capital structure and acquisition choices. Journal of Financial Economics, 102(3), 602-620.

Vermaelen, T., Xu, M. (2012). Acquisition finance, capital structure and market timing. Working Paper, Institut Europeen d'Administration (INSEAD), London School of Economics.

Warr, R. S., Elliott, W. B., Koeter-Kant, J., Oztekin, O. (2012). Equity mispricing and leverage adjustment costs. Journal of Financial and Quantitative Analysis, 47(3), 589-616.

Weston, J. F. (2001). Merger and Acquisitions as Adjustment Processes. Journal of Industry, Competition and Trade, 1(4), 395-410.

Yang, T. (2011). The adjustment of capital structure in mergers and acquisitions: a revisit of the optimal capital structure. Working Paper. http://citeseerx.ist.psu.edu/viewdoc/download?doi=10.1.1.557.477\&rep=rep1\&type=pdf

Zhou, Q., Tan, K. J. K., Faff, R., Zhu, Y. (2016). Deviation from target capital structure, cost of equity and speed of adjustment. Journal of Corporate Finance, 39, 99-120. 